\title{
Using Personalized Education to Take the Place of Standardized Education
}

\author{
Pengyu Gao \\ Correspondence: Pengyu Gao, College of Education, University of Oregon, Eugene, OR 97403-1215, USA.
}

\author{
Received: November 6, 2013 Accepted: November 24, 2013 Online Published: January 24, 2014 \\ doi:10.11114/jets.v2i2.269 \\ URL: http://dx.doi.org/10.11114/jets.v2i2.269
}

\begin{abstract}
Economic model has been greatly shifted from labor demanding to innovation demanding, which requires education system has to produce creative people. This paper illustrates how traditional education model accrued and developed based on satisfying the old economic model for labor demanding but did not meet the new social requirement for innovation demanding. Also, this paper illustrates how U.S. education reform movement turns into standardization movement that has been trapped by traditional education concept, for example, this standardization movement aims to produce great test takers, but fails to produce creative people with critical thinking skill. As well as this paper discusses how personalized education has been mentioned by Dr. Yong Zhao as a new model that focuses on exploring students' personal potential of innovation, which means personalized education is able to better adapt the modern society for innovation demanding, and it should take the place of standardized education.
\end{abstract}

Keywords: education, economy, personalization, standardization, creativity

\section{Introduction}

Zhao (2010) stated "Education is a future-oriented business because it aims to prepare today's children for the future". From that definition we know education is preparing our children for the future, however our current education has been established based on the experience from the past, this does not disturb us when we are living in an unaltered world, nevertheless, it is not the case for today. We are currently in a particular age, economic model has been greatly shifted, and a broad range of technologies are taking the place of human positions. In 2009, the "CNN News" stated, "The U.S. economy continued to hemorrhage jobs ... the unemployment rate to its highest level in 25 years" (Isidore, 2009), the situation is still not optimistic today. However, the blog "In Demand Careers That Didn't Exist 10 Years Ago" also told us "there are also new jobs that didn't exist 10 years ago... people are shifting from their common job to the "new job' because of its high demand, and high income opportunity" (Gaspay, 2013). I believe this trend of dramatic changes will continue into the future in which our children will live. If we still believe one of the most significant purposes of our education is to prepare our children for turning into the professionals that can create values in the society, we have to ask the question "How to produce some changes in our education system in order to adapt the social changes"? Of course, before we look into the future, we have to talk about how the current education model has been established based on the past experience to satisfy the old social and economic needs, and why the old way no longer works out, and what the new way we need is? In addition, before the concept of personalized education has been posted out as a new way, we will also observe what efforts the US education system and government have already made to produce changes, and why it was missing the target?

\section{Traditional Education - to Satisfy the Industrialism}

Ken Robinson (2006) in his TED talk "How Schools Kill Creativity" said, "The whole system was invented -- around the world, there were no public systems of education, really, before the 19th century. They all came into being to meet the needs of industrialism". If we look into the history, we will find out the public education was actually to satisfy the industrialism for numerous trained labors demanding, as Patricia Hinchey (2004) wrote "traditional economic goals: schools are expected...to produce hard workers" (P. 68). Under this background, the traditional education model has been developed to aim at suppressing the difference and critical thinking, as well as training students with highly submissiveness and skills useful for manufactory productivity.

\subsection{Traditional Education Model: Stop Critical Think}

One of the key requirements for manufactory workers is submissiveness, workers need to be proficient in some certain skills of productivity and repeat the same work every day mechanically. There is no need for a worker to think critically 
or to be creative. This certain circumstance makes schools traditionally like to previously train students to meet their future requirements at work, that is the reason why schools always highlight the discipline, and train students to be obedient, to do what teachers ask to do, to memorize what teachers ask to memorize. The factories prefer all workers to be similar, the diversity is obliviously not helpful for manufactory management. As well as in school, for a long time, the diversity was not celebrated, there was a perfect model for students, and teachers hoped all students could meet the same model, as to learn and memorize what they had been taught, and did well in the tests. There was no encouragement for being different, proposing personal views and thinking critically. Although we may not frankly say we discourage for being different today, the diversity has not been encouraged either, this has been reflected by the narrow selections and the hierarchy of different subjects in current education.

\subsection{Traditional Education model: Hierarchy in the Subjects}

Ken Robinson (2006) said, "So the hierarchy is rooted on two ideas. Number one, that the most useful subjects for works are at the top". That is the reason that our traditional education only emphasizes some specific subjects such as mathematics, science and literature in order to meet the social needs under industrialism. For example, how many times that we have heard people were talking to their kids "stop doing art, you can't find a job from doing this". In the old time, that could be the case, because manufactories needed workers to read and calculate, but seldom needed someone to make art. Therefore, the goal of our traditional education model is to make our students be good at some specific subjects that we think might be useful for the job market. However, as the whole industry shifted, this education model also needs changing. Lorelle in her blog "How to Teach Students for Jobs That Don't Exist" also stated "Technology is evolving at a speed where it seems that the human race cannot keep pace with innovation. If you want to prepare students of today for the world of tomorrow, then you must teach them to adapt to new ideas, helping them explore innovative concepts on their own". The traditional education does not value the skill of being creative, however, creativity has already become the most essential quality that our kids should have in the modern society, and hence, the goal of our modern education should be making our students develop the ability of creativity.

\section{Today's Effort-- Standardization Movement}

In the book The Death and the Life of the Great American School System, Diane Ravitch (2011) stated, "President George W. Bush's No Child Left Behind program...changed the nature of public schooling system across the nation by making standardized test scores the primary measure of school quality" (P. 15). On one hand, the society more and more emphasizes the importance of creativity and innovation. On the other hand, the US government is using political power to force us to go to the opposite direction, which is the standardization movement,

\subsection{Standardization Movement-Missing the Target}

Creativity means being unique or different, however, standardization means making all students homogeneous, as Hinchey (2004) wrote "in this context, schools become a kind of factory and students become products" (P. 69). Obliviously, the standardization movement will produce huge negative impacts. In addition, when the standardization movement turns into the testing movement, it makes the situation even worse. As Ravitch (2011) stated, "The rise or fall of test scores in reading and mathematics became the critical variable in judging students, teachers, principals, and schools" (P. 15). As the tests become the primary measure, it encourages our kids to give out the correct answers that have already been set up, by doing this way, we actually discourage our kids to think critically or to be creative. Very soon we will see our kids in a situation that "rather than learn what interests us, we study, memorize, and give back what those who control our grades tell us to" wrote Robert Fried (2005, P. 31). Furthermore, the tests are only emphasizing a few subjects, they do not value each kid equally. Although reading and mathematics are very important, that does not mean other subjects are less important. People are naturally different, the diversity is among the children since they were born, our kids are good at different things, at the same time when some of our kids have talent of doing calculation, for others kids must be good at something else, for example, they might be good at art or music. Our education should help our kids magnify their strong points, but not disvalue them. Unfortunately, when we are using tests to emphasize some specific subjects, actually we are forcing our kids to give up those talents that cannot be reflected by the tests.

\subsection{To follow the Policy, or to be Punished}

In another aspect, as we are linking the test with rewards and penalties, it makes schools have no choice but follow the policy. Ravitch (2011) told us that the test is not only a pressure for students, but also a huge pressure for schools. The test scores directly impact how much funding schools can get (P. 94-111). This policy forces schools to put more resources in those subjects that tests emphasize, therefore, this policy traps our schools in the old education model, as Zhao (2013) stated, "Standardized tests scores will soon fill almost all US classrooms and squeeze out any room for creativity". The modern society needs creative people, but not people are only able to give out correct answers in the exams, we are no longer living in the age of industrialism that needed thousands of workers to work in the 
manufactories to do the mechanical work, the technologies are taking the place of human capitals, as Zhao (2012) in his speech "World Class Learners: Educating Creative and Entrepreneurial Students" gave us an example that some of the biggest companies like Facebook, Twitter don't have big factories to hire thousands of people. The modern society needs people to create different new fields, but not follow the old way.

\section{Personal Education}

We have already discussed a lot how important the creativity is, and how our current education system is missing the target of helping our students be creative, therefore, we need to consider how to produce changes.

\subsection{Education Change from Standardization to Personalization}

In his speech, Zhao (2012) gave out the answer that is to use personalized education to take the place of standardized education. Zhao (2012) indicated a theory that "creativity cannot be taught, but can be killed"; therefore, being a teacher is not as easy as passing or teaching the knowledge to the students. In the book How Children Fail, John Holt (1982) wrote, "They fail to develop more than a tiny part of the tremendous capacity for learning, understanding, and creating with which they were born and of which they made full use during, the first two or three years of their lives" (P. 5). Holt once again indicated that kids must be good at something, and interested in them naturally, as well as kids will have patient to explore those fields, however, our education fails to help our kids to maintain and develop those talents. Winston Churchill once said "I'm always ready to learn, although I do not always like being taught", traditionally we are only passing the knowledge to the kids and commanding them to memorize it in order to earn points in the tests, actually we are killing student's skills of finding questions, exploring for answers, thinking critically and being creative. Our education should give students more chance of leaning, to encourage them to explore the knowledge. This requires our education to shift from standardization to personalization, our schools need to help our students find out their unique strong points, then the work of our education should aim at helping students magnify them, and encouraging students to develop skills of learning, critical thinking and being creative. Only by doing this, can we prepare our kids for turning into professionals that can make great and new contributions in their own skilled fields, as Zhao (2011) wrote, "We need to view students as global entrepreneurs in the sense that they need to become owners of their own learning and develop a globally-oriented entrepreneurial spirit".

\subsection{Left Behind or Lead the New Way}

As some people are afraid that their children might be left behind, people are also afraid that the nation might be left behind. The "ABC News" said, "Today, the new international reading, math, and science scores were released, and Chinese students left American teens in the dust in all three categories" (Diane, 2010). Those concerns might exactly be the factors that make the policy to be called "No Child Left Behind" as we mentioned before. Albert Einstein once said "If you judge a fish by its ability to climb a tree, it will live its whole life believing that it is stupid". It is the same when we are talking about a child or a nation. It is the reality that American kids have bad test scores, but it is not a new thing. Washington Post reporter Valeria Strauss wrote (2000) "For near 20 years, business, political and academic leaders have been sounding this warning: American students are global underachievers in math and science, posting a serious threat to competitiveness of US economy". Although politicians have been threatening people for longtime, decades past, US still has the strongest economy and maintains the dominant position under globalization. Actually, Zhao believes it is not a bad thing that US students cannot get good scores, as Zhao (2013) wrote in his article "U-Turn to Prosperity"

But for historical reasons, the United States is not as good at "sausage-making education" (standardized education) as most other countries are. A decentralized education system that allows local autonomy, the lack of a national curriculum, a broad conceptualization of success that tolerates diversity, and teaching practices that respect individual differences have made U.S. schools relatively ineffective in producing students who score high on standardized international tests. But this very ineffectiveness has made schools more successful in preserving students' creative and entrepreneurial talents.

Zhao (2013) also wrote "the United States must take a U-turn in our education policy, we must return to the traditional strengths of U.S. education: multiple criteria for judging education success, tolerance for difference and diversity, a broad curriculum". In addition, Zhao in an interview indicated, "Playing 'catch up' with developing nations makes no senses for U.S." (Richardson, 2010). From Zhao's (2013) theory, we know if the education emphasizes the standardization by using test to make all children go into the same model, our kids will lose their skills of thinking critically and being creative. Standardized education model is based on industrialism and manufactured economic model, it will produce a lot of traditional job seekers but not job makers. Looking back to the examples of Facebook and Twitter, In Zhao's (2012) speech, he indicated, our kids cannot aim at trying to find a job in this kind of companies, but should try to create a new one. Only when we are using personalized education to take the place of standardized education, can we no longer follow the old ways, but encourage our kids to create new things in their skilled areas, and to continue leading the global economy in new ways. 


\section{Discussion}

Education is preparing our children for the future, we can forecast the future will be dramatically different from the past, the technology will take the place of human positions, and new industry will take the place of old industry. Instead of trying to find a job in the old industry, we need people to create new industry to provide new jobs. Rather than great test takers, we more need students with creative and entrepreneurial spirit. We need personalized education to help our kids magnify their unique talents, and to develop their personal potential, and we should not try to use standardized education to trap them in the tests.

Under the globalization age, we are having lots of students with very different backgrounds. We are in a special age and have incredible diversity in our classroom. Being creative means being different and diverse. In this globalization age, students have the great convenience of experiencing more diversity in their classroom. We should well use this great opportunity, if we want to standardize everything, this diversity would be an obstacle of the movement. However, if we want our students to get inspiration from the diversity, this would be our great support.

\section{References}

Fried, R. L. (2005). The game of school: Why we all play it, how it hurts kids, and what it will take to change it. Jossey-Bass Inc Pub.

Gaspay, D. (2013, May 21). In demand careers that didn't exist 10 years ago. [Blog post]. Retrieved from http://fromhobby2money.blogspot.com/2013/03/in-demand-careers-that-didnt-exist-10.html.

Hinchey, P. H. (2004). Becoming a critical educator: defining a classroom indentity, designing a critical pedagogy (Vol. 224). Peter Lang.

Holt, J. C. (1982). How children fail. Da Capo Press.

Isidore, C. (2009. March 6). Unemployment hits 25-year high. CNN Money. Retrieved from http://money.cnn.com/2009/03/06/news/economy/jobs_february/.

Lorelle, A. How to teach students for jobs that don't exist yet. [Blog post]. eHow. Retrieved from http://www.ehow.com/how_7909655_teach-jobs-dont-exist-yet.html.

Ravitch, D. (2011). The death and life of the great American school system: How testing and choice are undermining education. Basic Books.

Richardson, J. (2010). Playing'Catch-Up'with Developing Nations Makes No Sense for US AN INTERVIEW WITH YONG ZHAO. Phi Delta Kappan, 91(4), 15-20.

Robinson, K. (2006, Febrary). How schools kill creativity. [Video file]. TED Talk. Retrieved from http://www.ted.com/talks/ken_robinson_says_schools_kill_creativity.html.

Sawyer, D. (2010, December 7). China beats U.S. in reading, math, and science. [Video file]. ABC News. Retrieved from

http://abcnews.go.com/WNT/video/china-beats-us-reading-math-science-score-education-american-children-1233 8330.

Strauss, V. (2000, December 26). When success doesn't add up: How can a "Nation at Risk" continue to thrive when U.S. students score so poorly on math and science tests? The Washington Post.

Zhao, Y. (2010). Preparing globally competent teachers: A new imperative for teacher education. Journal of Teacher Education, 61, 422-431. http://dx.doi.org/10.1177/0022487110375802.

Zhao, Y. (2011). Students as change partners: A proposal for educational change in the age of globalization. Journal of Educational Change, 267-279. http://dx.doi.org/10.1007/s10833-011-9159-9.

Zhao, Y. (2012, Novenber 29). World Class Learners: Educating Creative and Entrepreneurial Students. [Video file]. Retrieved from http://www.youtube.com/watch?v=CGOInNGMovk.

Zhao, Y. (2013). U-Turn to Prosperity. The Jossey-Bass Reader on Educational Leadership, 441.

\section{$(\mathrm{cc}) \mathrm{Br}$}

This work is licensed under a Creative Commons Attribution 3.0 License. 